\title{
ANALISIS KOMPETENSI SUMBER DAYA MANUSIA PADA DINAS PEKERJAAN UMUM DAN PENATAAN RUANG KOTA BOGOR
}

\author{
ANALYSIS OF HUMAN RESOURCE COMPETENCY \\ IN LOCAL OFFICE OF PUBLIC WORK AND SPATIAL PLANNING \\ IN BOGOR CITY
}

\author{
Olisah $^{1 *}$, Denny Hernawan ${ }^{2}$, Irma Purnamasari ${ }^{3}$ \\ 1,2,3Program Studi Administrasi Publik, Fakultas Ilmu Sosial dan Ilmu Politik, Universitas \\ Djuanda, Jl. Tol Ciawi No. 1, Kotak Pos 35, Bogor 16720 \\ ${ }^{*}$ Korespondensi: Olisah. Email: olisah@unida.ac.id
}

(Diterima: 14-05-2019; Ditelaah: 24-06-2019; Disetujui: 07-08-2019)

\begin{abstract}
The aim of this research is to describe the competency of human resources, namely civil servants, and the obstacles faced by the Local Office of Public Work and Spatial Planning in Bogor City. The theory of this research stems from Spencer and Spencer's theory on competency, including five dimensions, namely knowledge, skill, trait, self-concept, and motive. The method of this research is descriptive method. The samples of this research determine 54 respondents from 117 civil servants. The data of this research is collected by using the field research (observation, interview, and questionnaire) to collect primary data and the library research to collect secondary data. The data of questionnaires is analyzed by using the Weight Mean Score formula to count the mean score. The secondary data is used to enrich the discussion of this research. The result of this research indicate the mean score of civil servant competency 4.25 included in best criteria. It means that a majority of civil servants has good competency to conduct the main task and function in order to achieve the goals of the local office. Moreover, there are still some civil servants who have not competencies, as indicated in the lack of skill certificate, formal education, and training.
\end{abstract}

Keywords: Competency, Human Resource, Civil Servant.

\begin{abstract}
ABSTRAK
Tujuan penelitian ini adalah untuk mengetahui kompetensi sumber daya manusia pegawai negeri sipil dan hambatannya pada Dinas Pekerjaan Umum dan Penataan Ruang Kota Bogor. Teori penelitian ini bersumber dari teori kompetensi Spencer dan Spencer, yang di dalamnya terdapat 5 dimensi, yaitu dimensi pengetahuan, ketrampilan, watak, konsep diri, dan motif. Metode penelitian ini adalah metode deskriptif. Sampel penelitian ditentukan sebanyak 54 pegawai dari 117 pegawai. Adapun teknik pengumpulan data dilakukan dengan menggunakan studi lapangan (observasi, wawancara, dan kuesioner) untuk mengumpulkan data primer dan studi kepustakaan untuk mengumpulkan data sekunder. Analisis data kuesioner dilakukan dengan menggunakan rumus Weight Mean Score untuk menghitung skor rata-rata. Data sekunder digunakan untuk memperkaya pembahasan. Hasil penelitian menunjukkan skor rata-rata kompetensi pegawai sebesar 4,25 yang termasuk dalam kriteria sangat baik. Ini berarti bahwa sebagian besar pegawai memiliki kompetensi yang baik untuk melaksanakan tugas pokok dan fungsi sehingga dapat membantu pencapaian tujuan dari dinas. Di samping itu, masih terdapat pegawai yang tidak memiliki kompetensi. Hal ini dibuktikan dengan masih cukup rendahnya kepemilikan sertifikat ketrampilan pendukung, latar belakang pendidikan dan keikutsertaan pegawai mengikuti pendidikan dan pelatihan.
\end{abstract}

Kata Kunci: Kompetensi, Sumber Daya Manusia, Pegawai Negeri Sipil.

Olisah. 2019. Analisis Kompetensi Sumber Daya Manusia pada Dinas Pekerjaan Umum dan Penataan Ruang Kota Bogor. 


\section{PENDAHULUAN}

Di dalam era globalisasi, masalah sumber daya manusia menjadi tumpuan bagi organisasi baik pemerintah maupun swasta. Sumber daya manusia merupakan harta atau aset yang berharga yang dimiliki oleh suatu organisasi dan juga yang menentukan keberhasilan pencapaian tujuan organisasi. Dalam mencapai keberhasilan, organisasi diperlukan landasan yang kuat berupa sumber daya manusia yang memiliki kompetensi. Kompetensi tersebut berupa pengetahuan, ketrampilan dan sikap yang merupakan komponen kunci dalam manajemen yang memainkan peranan penting dan strategis dalam meningkatkan kinerja pegawai.

Selain itu, tujuan dilaksanakannya peningkatan kompetensi dalam organisasi adalah karena adanya tuntutan pekerjaan sebagai akibat kemajuan ilmu pengetahuan dan teknologi serta tuntutan masyarakat yang meminta agar pelayanan semakin mudah, murah dan cepat. Kompetensi berhubungan dengan kemampuan untuk melaksanakan atau melakukan suatu pekerjaan atau tugas yang dilandasi atas ketrampilan dan pengetahuan serta didukung oleh sikap kerja yang dituntut oleh pekerjaan tersebut sehingga pegawai dapat melaksanakan tugasnya secara profesional, efisien, dan efektif.

Dalam hal ini, organisasi memerlukan pegawai yang memiliki kompetensi teknis maupun kompetensi manajerial untuk menjalankan organisasi. Peraturan Kepala Badan Kepegawaian Negara No. 8 Tahun 2013 tentang Pedoman Perumusan Standar Kompetensi Teknis Pegawai Negeri Sipil dan Peraturan Kepala Badan Kepegawaian Negara No. 7 Tahun 2013 tentang Pedoman Perumusan Standar Kompetensi Manajerial Pegawai Negeri Sipil mengatur agar pegawai negeri sipil mempunyai kompetensi teknis dan kompetensi manajerial. Untuk mendukung terwujudnya profesionalisme pegawai negeri sipil diperlukan standar kompetensi jabatan yang wajib dimiliki oleh setiap pegawai, yang terdiri dari standar kompetensi teknis dan standar kompetensi manajerial.

Standar kompetensi teknis mencerminkan tuntutan aspek pengetahuan, ketrampilan, dan sikap yang dibutuhkan dalam melaksanakan tugas pekerjaan yang bersifat teknis. Sedangkan kompetensi manajerial adalah soft competency yang mencakup aspek pengetahuan, ketrampilan dan sikap sesuai tugas atau fungsi jabatan. Dalam hal ini, kompetensi manajerial pegawai didefinisikan sebagai persyaratan kompetensi manajerial minimum yang harus dimiliki seorang pegawai dalam melaksanakan tugas jabatan. Peraturan Kepala BKN tersebut menuntut organisasi pemerintah/instansi untuk melaksanakan aturan tersebut, dimana pengalokasian pegawai pada suatu instansi harus lebih banyak pegawai yang memiliki kompetensi teknis dibandingkan dengan pegawai yang memiliki kompetensi manajerial.

Penelitian ini dilakukan pada Dinas Pekerjaan Umum dan Penataan Ruang Kota Bogor sebagai perangkat daerah yang melaksanakan tugas dan menyelesaikan pekerjaan pada bidang teknis. Fungsi dinas tersebut di antaranya perumusan kebijakan teknis, penyelenggaraan kebinamargaan, pemeliharaan kebinamargaan, penyelenggaraan urusan pemerintahan dan pelayanan umum di bidang pekerjaan umum dan penataan ruang. Tentunya saja, dinas tersebut perlu didukung oleh pegawai yang memiliki kompetensi yang andal, yang meliputi pengetahuan, ketrampilan dan sikap, sehingga sangat tepat apabila kompetensi yang dimiliki oleh pegawai menjadi prioritas untuk ditingkatkan agar pegawai tersebut dapat dikatakan pegawai dengan kompetensi yang baik.

Sesuai dengan Peraturan Kepala BKN No. 7 Tahun 2013 dan Peraturan Kepala BKN No. 8 Tahun 2013, Dinas Pekerjaan Umum dan Penataan Ruang Kota Bogor memiliki pegawai dengan jumlah 117 orang. Dari jumlah ini, pegawai yang memiliki 
kompetensi manajerial sebanyak 24 orang; selebihnya adalah pegawai yang seharusnya memiliki kompetensi teknis. Pengalokasian ini sesuai dengan peraturan tersebut dimana dalam suatu organisasi pemerintah dibutuhkan pegawai yang bersifat teknis dalam jumlah besar. Akan tetapi pada kenyataannya Dinas Pekerjaan Umum dan Penataan Ruang belum bisa dikatakan memiliki pegawai dengan kompetensi yang baik. Hal ini terbukti dengan masih cukup banyaknya pegawai yang merupakan lulusan SLTA (Tabel 1).

Tabel 1. Tingkat Pendidikan Pegawai Dinas Pekerjaan Umum dan Penataan Ruang Kota Bogor

\begin{tabular}{clcc}
\hline No. & Pendidikan & PNS & Jumlah \\
\hline 1. & S-2 & 20 & 20 \\
\hline 2. & S-1 & 31 & 31 \\
\hline 3. & D-III & 7 & 7 \\
\hline 4. & D-II & - & - \\
\hline 5. & D-I & - & - \\
\hline 6. & SLTA & 49 & 49 \\
\hline 7. & SLTP & 4 & 4 \\
\hline 8. & SD & 2 & 2 \\
\hline
\end{tabular}

Sumber: Dinas Pekerjaan Umum dan Penataan Ruang Kota Bogor (2018)

Selain itu, kompetensi pegawai tidak hanya dilihat dari latar belakang pendidikannya tetapi juga dilihat dari ketrampilan yang dimiliki. Hal ini dapat ditandai dengan adanya sertifikat ketrampilan pendukung yang harus dimiliki oleh pegawai. Dari 117 pegawai pada Dinas Pekerjaan Umum dan Penataan Ruang Kota Bogor ternyata terdapat hanya 9 pegawai yang memiliki sertifikat ketrampilan pendukung. Sehingga dari data tersebut dapat disimpulkan bahwa pegawai yang kompeten secara teknis hanya 9 orang. Hal ini juga disebabkan karena ketidakikutsertaan pegawai dalam pendidikan dan pelatihan (diklat) baik diklat teknis maupun manajerial, dalam satu tahun pegawai yang mengikuti diklat hanya satu orang dan inipun diklatpim atau diklat untuk kenaikan jabatan. Pada hal Dinas Pekerjaan Umum dan Penataan Ruang Kota Bogor merupakan dinas yang bersifat teknis akan tetapi tidak terdapat pegawai yang mengikuti diklat teknis.
Berdasarkan gambaran latar belakang tersebut, maka tujuan penelitian ini adalah untuk mengetahui kompetensi pegawai dan hambatan yang dihadapi dalam peningkatan kompetensi pegawai pada Dinas Pekerjaan Umum dan Penataan Ruang Kota Bogor.

\section{MATERI DAN METODE}

\section{Teori/Konsep yang Relevan}

Seiring dengan perkembangan teknologi dan lingkungan yang cepat pada setiap aspek kehidupan manusia, organisasi pemerintah membutuhkan sumber daya manusia yang memiliki kompetensi agar dapat memberikan pelayanan yang memuaskan kepada masyarakat. Beberapa ahli berpandangan bahwa kompetensi seseorang akan menghasilkan kinerja yang baik dengan rumus kompetensi sama dengan kinerja.

Peneliti menggunakan teori Spencer dan Spencer (Moeheriono, 2014), dimana kompetensi adalah suatu kemampuan untuk melaksanakan atau melakukan suatu pekerjaan atau tugas yang dilandasi atas dasar pengetahuan dan ketrampilan serta didukung dengan sikap kerja yang dituntut oleh pekerjaan tersebut. Kompetensi di sini dapat dinilai dengam melihat dimensidimensi dari kompetensi, yaitu dimensi pengetahuan, dimensi ketrampilan, dimensi watak, dimensi konsep diri, dan dimensi motif.

\section{Metode}

Peneliti menggunakan metode penelitian deskriptif, yaitu penelitian yang dilakukan untuk mengetahui nilai variabel mandiri, baik satu variabel maupun lebih tanpa membuat perbandingan atau menghubungkan dengan variabel yang lain (Sugiyono, 2012).

Populasi penelitian mencakup seluruh pegawai Dinas Pekerjaan Umum dan Penataan Ruang Kota Bogor yang berjumlah 117 orang. Banyaknya sampel yang diteliti 
ditentukan dengan menggunakan rumus Slovin (Sugiyono, 2012) sebagai berikut:

$$
\mathrm{n}=\frac{N}{1+N e^{2}}
$$

Keterangan:

$\mathrm{N}$ : Ukuran sampel

$\mathrm{N}$ : Populasi

e: Presisi (perkiraan kesalahan

yang ditentukan, yaitu 0,1).

Dengan rumus tersebut diperoleh sampel berjumlah 54 orang pegawai, dengan taraf kesalahan sebesar $10 \%$. Teknik sampel yang digunakan adalah random sampling dimana semua anggota populasi memiliki kesempatan yang sama untuk dijadikan sampel penelitian.

Data yang dikumpulkan untuk penelitian terdiri dari data primer dan sekunder. Pengumpulan data penelitian menggunakan dua teknik sebagai berikut:

1. Penelitian Lapangan (Field Research), yaitu penelitian yang dilakukan secara langsung ke lapangan untuk memperoleh data primer menyangkut permasalahan yang menjadi objek penelitian. Teknik penelitian lapangan yang dipakai adalah observasi, wawancara, dan kuesioner.

2. Studi Kepustakaan (Library Research), yaitu penelitian untuk memperoleh data sekunder dari penelitian terdahulu, pustaka, dokumen, dan peraturan yang ada. Teknik studi kepustakaan yang dipakai adalah kajian pustaka dan dokumentasi.

Teknik analisis data adalah proses penyederhanaan data ke dalam bentuk yang lebih mudah dibaca, dipahami serta mudah diinterpretasikan (Sugiyono, 2012). Analisis data menggunakan statistik deskriptif yang bertujuan untuk menafsirkan hasil analisis secara jelas dan luas. Peneliti menggunakan skala Likert untuk mengukur jawaban responden dari kuesioner. Analisis dilakukan dengan menentukan skor dari tiap jawaban responden dengan rumus:

$$
\begin{array}{cl}
\text { I }=\frac{S K T-S K R}{v} & I=\frac{5-1}{5}=0,8 \\
\text { Keterangan: } & \\
\text { I } & : \text { Interval } \\
\text { SKT } & : \text { Skor Tertinggi } \\
\text { SKR } & : \text { Skor Terendah } \\
\text { V } & \text { : Jumlah }
\end{array}
$$

Adapun untuk keperluan analisis data, maka jawaban responden diberi skor (Tabel 2).

Tabel 2. Jawaban Responden

\begin{tabular}{ll}
\hline Jawaban & Skor Nilai \\
\hline Sangat Baik & 5 \\
\hline Baik & 4 \\
\hline Cukup Baik & 3 \\
\hline Tidak Baik & 2 \\
\hline Sangat Tidak Baik & 1 \\
\hline Sumber: Sugiyono (2012) &
\end{tabular}

Hasil perhitungan dari 0,8 dijadikan patokan untuk kriteria penilaian. Dari ketentuan tersebut di atas ditentukan kriteria penilaian (Tabel 3).

Tabel 3. Kriteria Penilaian Berdasarkan Angka Penafsiran

\begin{tabular}{ll}
\hline Rentang Skor & Kriteria \\
\hline $1,00-1,80$ & Sangat Tidak Baik \\
\hline $1,80-2,60$ & Tidak Baik \\
\hline $2,60-3,40$ & Cukup Baik \\
\hline $3,40-4,20$ & Baik \\
\hline Sumber: Sugiyono (2012) & Sangat Baik \\
\hline
\end{tabular}

Analisis data penelitian menggunakan perhitungan Weight Mean Score (WMS), yaitu uraian yang berupa penggambaran untuk menjelaskan jawaban-jawaban yang diberikan responden dalam kuesioner. Rumus WMS adalah sebagai berikut:

$$
\mathrm{M}=\frac{\Sigma f(x)}{n}
$$

\section{Keterangan:}

M: perolehan angka penafsiran kriteria penafsiran

$\Sigma$ : penjumlahan

f: frekuensi jawaban responden

$\mathrm{x}$ : pembobotan (skala nilai)

$\mathrm{n}$ : jumlah sampel penelitian. 
Hasil pengolahan data jawaban responden berdasarkan WMS (Tabel 4) ditabulasikan sebagai berikut:

Tabel 4. Alternatif Jawaban Responden



Sumber: Sugiyono (2012)

Data-data yang diperoleh melalui wawancara dan studi pustaka digunakan untuk memperdalam pembahasan hasil penghitungan WMS terhadap setiap item pertanyaan dalam angket.

\section{HASIL DAN PEMBAHASAN}

Hasil penelitian dibahas berdasarkan dimensi-dimensi kompetensi SDM pegawai pada Dinas Pekerjaan Umum dan Penataan Ruang Kota Bogor sebagai berikut:

Tabel 5. Rekapitulasi Dimensi Pengetahuan

\begin{tabular}{llcc}
\hline Dimensi & Indikator & $\begin{array}{c}\text { Angka } \\
\text { Penafsiran }\end{array}$ & $\begin{array}{c}\text { Kriteria } \\
\text { Penafsiran }\end{array}$ \\
\hline & $\begin{array}{l}\text { Kesesuaian latar } \\
\text { belakang pendi- } \\
\text { dikan dengan } \\
\text { pekerjaan }\end{array}$ & 4,05 & Baik \\
\cline { 2 - 4 } & $\begin{array}{l}\text { Pemahaman ter- } \\
\text { hadap prosedur } \\
\text { pekerjaan }\end{array}$ & 4,22 & $\begin{array}{c}\text { Sangat } \\
\text { Baik }\end{array}$ \\
\cline { 2 - 4 } $\begin{array}{l}\text { Pengeta- } \\
\text { huan }\end{array}$ & $\begin{array}{l}\text { Pengetahuan } \\
\text { menyelesaikan } \\
\text { pekerjaan }\end{array}$ & 4,33 & $\begin{array}{c}\text { Sangat } \\
\text { Baik }\end{array}$ \\
\cline { 2 - 4 } & $\begin{array}{l}\text { Pengalaman } \\
\text { bekerja pada } \\
\text { bidang ini } \\
\text { sebelumnya }\end{array}$ & 3,66 & Baik \\
\hline Jumlah & \multicolumn{2}{c}{ B,06 } & Baik \\
\hline Sumber: Data Hasil Penelitian yang Diolah, 2019
\end{tabular}

Pada Tabel 5, rekapitulasi dimensi pengetahuan di atas memiliki angka penafsiran sebesar 4,06 dengan kriteria penafsiran baik. Hal ini dapat diartikan bahwa sebagian besar pegawai dinas memiliki pengetahuan yang baik. Tetapi pada kenyataannya berdasarkan observasi langsung di lapangan masih cukup banyak pegawai yang tidak sesuai antara penempatan kerja dengan latar belakang pendidikan sebelumnya. Selain itu, pegawai dinas tersebut rata-rata tidak memiliki pengalaman bekerja pada bidang ini sebelumnya. Sehingga belum dapat dikatakan bahwa pegawai dinas tersebut memiliki pengetahuan tentang tugas pokok dan fungsinya.

Tabel 6. Rekapitulasi Dimensi Ketrampilan

\begin{tabular}{|c|c|c|c|}
\hline Dimensi & Indikator & $\begin{array}{c}\text { Angka } \\
\text { Penafsiran }\end{array}$ & $\begin{array}{c}\text { Kriteria } \\
\text { Penafsiran }\end{array}$ \\
\hline \multirow{4}{*}{$\begin{array}{l}\text { Ketram- } \\
\text { pilan }\end{array}$} & $\begin{array}{l}\text { Memiliki ketram- } \\
\text { pilan untuk } \\
\text { menyelesaikan } \\
\text { pekerjaan }\end{array}$ & 4,22 & $\begin{array}{l}\text { Sangat } \\
\text { Baik }\end{array}$ \\
\hline & $\begin{array}{l}\text { Memiliki ketram- } \\
\text { pilan secara teknis }\end{array}$ & 4,12 & Baik \\
\hline & $\begin{array}{l}\text { Memiliki ketram- } \\
\text { pilan secara } \\
\text { konseptual }\end{array}$ & 4,07 & Baik \\
\hline & $\begin{array}{l}\text { Memiliki serti- } \\
\text { fikat ketrampilan } \\
\text { kerja }\end{array}$ & 3,40 & $\begin{array}{l}\text { Cukup } \\
\text { Baik }\end{array}$ \\
\hline Jumlah & & 3,95 & Baik \\
\hline
\end{tabular}

Sumber: Data Hasil Penelitian yang Diolah, 2019

Pada Tabel 6, rekapitulasi dimensi ketrampilan memiliki angka penafsiran sebesar 3,95 dengan kriteria penafsiran baik. Artinya, sebagian besar pegawai dinas memiliki ketrampilan yang baik sebagai penunjang untuk menyelesaikan pekerjaan baik teknis maupun konseptual. Meskipun pada indikator kepemilikan sertifikat keahlian kerja, hampir sebagian besar pegawai tidak memilikinya sehingga masih perlu dipertanyakan pegawai tersebut benar-benar trampil atau tidak pada bidang pekerjaan yang menjadi tugas pokok dan fungsinya.

Tabel 7. Rekapitulasi Dimensi Watak

\begin{tabular}{|c|c|c|c|}
\hline Dimensi & Indikator & $\begin{array}{c}\text { Angka } \\
\text { Penafsiran }\end{array}$ & $\begin{array}{c}\text { Kriteria } \\
\text { Penafsiran }\end{array}$ \\
\hline \multirow{3}{*}{ Watak } & $\begin{array}{l}\text { Merasa percaya } \\
\text { diri untuk menye- } \\
\text { lesaikan peker- } \\
\text { jaan dengan } \\
\text { kualitas yang baik }\end{array}$ & 4,22 & $\begin{array}{c}\text { Sangat } \\
\text { Baik }\end{array}$ \\
\hline & $\begin{array}{l}\text { Mampu beradap- } \\
\text { tasi dengan ling- } \\
\text { kungan pekerjaan }\end{array}$ & 4,5 & $\begin{array}{c}\text { Sangat } \\
\text { Baik }\end{array}$ \\
\hline & $\begin{array}{l}\text { Memiliki loyalitas } \\
\text { terhadap instansi } \\
\text { tempat bekerja }\end{array}$ & 4,51 & $\begin{array}{c}\text { Sangat } \\
\text { Baik }\end{array}$ \\
\hline Jumlah & & 4,41 & $\begin{array}{c}\text { Sangat } \\
\text { Baik }\end{array}$ \\
\hline
\end{tabular}

Sumber: Data Hasil Penelitian yang Diolah, 2019 
Pada Tabel 7, rekapitulasi dimensi watak memiliki angka penafsiran sebesar 4,41 dengan kriteria penafsiran sangat baik. Dapat diketahui bahwa sebagian besar pegawai dinas memiliki watak atau sifat yang baik pada lingkungan pekerjaannya. Sifat tersebut dapat ditandai dengan memiliki rasa percaya diri untuk menyelesaikan tugas pokok dan fungsinya, mengabdi kepada tempat kerjanya, dan mampu beradaptasi dengan cepat terhadap lingkungan yang baru, yaitu lingkungan pekerjaan, baik adaptasi dengan rekan kerja, pimpinan, aturan dan budaya organisasi yang terdapat pada tempat kerja tersebut. Dalam indikator berpenampilan rapi, terdapat aturan khusus mengenai pakaian yang digunakan setiap harinya sesuai dengan peraturan yang berlaku. Sehinggap seluruh pegawai mengikuti aturan tersebut, seperti senin dan selasa menggunakan pakaian dinas, rabu menggunakan pakaian adat sunda, kamis menggunakan batik dan jumat menggunakan pakaian olah raga atau bebas.

Tabel 8. Rekapitulasi Dimensi Konsep Diri

\begin{tabular}{|c|c|c|c|}
\hline Dimensi & Indikator & $\begin{array}{c}\text { Angka } \\
\text { Penafsiran }\end{array}$ & $\begin{array}{c}\text { Kriteria } \\
\text { Penafsiran }\end{array}$ \\
\hline \multirow{5}{*}{$\begin{array}{l}\text { Konsep } \\
\text { Diri }\end{array}$} & $\begin{array}{l}\text { Mampu berkomu- } \\
\text { nikasi dengan baik } \\
\text { sesama rekan kerja }\end{array}$ & 4,48 & $\begin{array}{l}\text { Sangat } \\
\text { Baik }\end{array}$ \\
\hline & $\begin{array}{l}\text { Membangun } \\
\text { hubungan kerja } \\
\text { yang positif }\end{array}$ & 4,5 & Baik \\
\hline & $\begin{array}{l}\text { Berpenampilan rapi } \\
\text { sesuai dengan } \\
\text { peraturan tempat } \\
\text { kerja }\end{array}$ & 4,55 & $\begin{array}{l}\text { Sangat } \\
\text { Baik }\end{array}$ \\
\hline & $\begin{array}{l}\text { Bertutur bahasa } \\
\text { yang baik }\end{array}$ & 4,5 & $\begin{array}{l}\text { Sangat } \\
\text { Baik }\end{array}$ \\
\hline & $\begin{array}{l}\text { Berperilaku yang } \\
\text { baik di lingkungan } \\
\text { kerja }\end{array}$ & 4,5 & $\begin{array}{c}\text { Sangat } \\
\text { Baik }\end{array}$ \\
\hline Jumlah & & 4,50 & $\begin{array}{l}\text { Sangat } \\
\text { Baik }\end{array}$ \\
\hline
\end{tabular}

Sumber: Data Hasil Penelitian yang Diolah, 2019

Pada Tabel 8, rekapitulasi dimensi konsep diri atau sikap memiliki angka penafsiran sebesar 4,50 dengan kriteria penafsira sangat baik. Sebagian besar pegawai dinas sangat baik ditandai dengan terjalinnya sikap serta hubungan yang baik antara atasan dengan bawahan. Meskipun hubungan dilakukan dengan cara yang berbeda antara hubungan sesama rekan kerja dan hubungan dengan atasan disesuaikan dengan etika kerja tapi tetap mengutamakan kekeluargaan dalam melaksanakan pekerjaan.

Tabel 9. Rekapitulasi Dimensi Motif

\begin{tabular}{|c|c|c|c|}
\hline Dimensi & Indikator & $\begin{array}{c}\text { Angka } \\
\text { Penafsiran }\end{array}$ & $\begin{array}{c}\text { Kriteria } \\
\text { Penafsiran }\end{array}$ \\
\hline \multirow{3}{*}{ Motif } & $\begin{array}{l}\text { Memiliki keinginan } \\
\text { bekerja lebih giat }\end{array}$ & 4,35 & $\begin{array}{c}\text { Sangat } \\
\text { Baik }\end{array}$ \\
\hline & $\begin{array}{l}\text { Bekerja untuk } \\
\text { memenuhi } \\
\text { keinginan dan } \\
\text { kebutuhan }\end{array}$ & 4,40 & $\begin{array}{c}\text { Sangat } \\
\text { Baik }\end{array}$ \\
\hline & $\begin{array}{l}\text { Bekerja untuk } \\
\text { meningkatkan } \\
\text { kemampuan dan } \\
\text { memiliki prestasi }\end{array}$ & 4,38 & $\begin{array}{c}\text { Sangat } \\
\text { Baik }\end{array}$ \\
\hline Jumlah & & 4,37 & $\begin{array}{c}\text { Sangat } \\
\text { Baik }\end{array}$ \\
\hline
\end{tabular}

Sumber: Data Hasil Penelitian yang Diolah, 2019

Pada Tabel 9, rekapitulasi dimensi motif memiliki angka penafsiran sebesar 4,37 dengan kriteria penafsiran sangat baik. Hal ini dapat diartikan bahwa pegawai dinas memiliki motif yang baik ketika melaksanakan pekerjaannya. Pegawai dinas menyadari akan pentingnya memenuhi kebutuhan dan keinginan untuk menunjang keperluan pokoknya berupa keinginan untuk mendapatkan kompensasi. Tetapi di sisi lain tidak dapat dipungkiri bahwa pegawai dinas tersebut memiliki motif untuk meningkatkan aktualisasi diri seperti contohnya mendapat penghargaan sebagai pegawai yang berprestasi.

Tabel 10. Rekapitulasi Variabel

Kompetensi Sumber Daya Manusia

\begin{tabular}{lll}
\hline Dimensi & $\begin{array}{l}\text { Angka } \\
\text { Penafsiran }\end{array}$ & $\begin{array}{l}\text { Kriteria } \\
\text { Penafsiran }\end{array}$ \\
\hline Pengetahuan & 4,06 & Baik \\
\hline Keterampilan & 3,95 & Baik \\
\hline Watak & 4,41 & Sangat Baik \\
\hline Konsep Diri & 4,50 & Sangat Baik \\
\hline Motif & 4,37 & Sangat Baik \\
\hline Jumlah & 4,25 & Sangat Baik \\
\hline
\end{tabular}

Sumber: Data Hasil Penelitian yang Diolah, 2019

Pada Tabel 10, hasil analisis menunjukkan bahwa variabel kompetensi sumber 
daya manusia memiliki angka penafsiran sebesar 4,25 dengan kriteria penafsiran sangat baik. Hal ini dapat diartikan bahwa sebagian besar pegawai Dinas Pekerjaan Umum dan Penataan Ruang Kota Bogor memiliki kompetensi yang mumpuni di bidang pekerjaannya. Meskipun masih ada satu dua hal yang harus diperbaiki dan ditingkatkan seperti keikutsertaan diklat dan sertifikat keahlian yang harus dimiliki apabila benar-benar ingin dikatakan sebagai pegawai yang kompeten.

\section{KESIMPULAN DAN REKOMENDASI}

\section{Kesimpulan}

Hasil penelitian dan pembahasan menunjukkan hal-hal yang dapat disimpulkan sebagai berikut:

1. Kompetensi pegawai Dinas Pekerjaan Umum dan Penataan Ruang Kota Bogor jika dilihat dari hasil penghitungan keseluruhan dapat dikatakan sangat baik, terbukti dari hasil jawaban responden sebesar 4,25 yang termasuk dalam kriteria sangat baik. Skor tertinggi terdapat pada dimensi konsep diri/sikap. Sedangkan untuk skor terendah terdapat pada dimensi ketrampilan.

2. Hambatan yang muncul dalam kaitan dengan usaha untuk meningkatkan kompetensi pegawai bersumber dari sistem perekrutan yang masih dinilai belum baik dan optimal karena seharusnya pengalokasian pegawai disesuaikan dengan Peraturan Kepala Badan Kepegawaian Negara Nomor 7 Tahun 2013 dan Peraturan Kepala Badan Kepegawaian Negara Nomor 8 Tahun 2013. Selain itu, standar perekrutan pegawai disesuaikan dengan merit system yang didahului dengan seleksi pegawai.

\section{Implikasi}

Penelitian ini sesuai dengan teori yang digunakan, yaitu teori dari Spencer dan Spencer, terdiri dari lima dimensi, yaitu dimensi pengetahuan, dimensi ketrampilan, dimensi watak, dimensi konsep diri, dan dimensi motif (Moeheriono, 2011).

Alasan peneliti menggunakan teori tersebut karena terdapat kesesuaian bahwa yang diperlukan dari organisasi itu adalah sumber daya manusia yang mumpuni yang ditandai dengan kompetensi yang dimiliki oleh seluruh pegawai pada organisasi tersebut. Kompetensi pokok yang harus dimiliki pegawai adalah pengetahuan, ketrampilan dan sikap (watak dan motif).

Sedangkan implikasi praktis dari penelitian analisis kompetensi sumber daya manusia ini dapat dijadikan sebagai bahan masukan untuk dinas terkait dalam meningkatkan kompetensi pegawainya. Dalam hal ini, yang harus diperbaiki adalah sistem perekrutan pegawai dan keikutsertaan pegawai dalam pendidikan dan pelatihan (diklat).

\section{DAFTAR PUSTAKA}

Buku:

Hasibuan, Malayu S. P. 2014. Manajemen Sumber Daya Manusia. Jakarta: Bumi Aksara.

Mangkunegara, A. A. Anwar Prabu. 2011. Manajemen Sumber Daya Manusia Perusahaan. Bandung: Remaja Rosdakarya.

Maulana, Irvan; Rahmawati, Rita dan Salbiah, Euis. 2017. Pengaruh Kepemimpinan Kepala UPT Puskesmas terhadap Kinerja Pegawai Puskesmas Ciawi Kecamatan Ciawi Kabupaten Bogor. Jurnal GOVERNANSI, Vol. 3 No. 1, April.

Moeheriono. 2014. Pengukuran Kinerja Berbasis Kompetensi. Jakarta: Ghalia Indonesia.

Palan, R. 2007. Competency Management: Teknis Mengimplementasikan Manajemen SDM Berbasis Kompetensi untuk Meningkatkan Daya Saing Organisasi. Jakarta: PPM. 
Purnamasari, Irma; Munjin, R. A. dan Ratnamulyani, Ike Atikah. 2019. Penataan Sumber Daya Manusia Berbasis Kompetensi. Jurnal GOVERNANSI, Vol. 5 No. 1, April.

Siagian, Sondang P. 2006. Organisasi, Kepemimpinan dan Perilaku Administrasi. Jakarta: Penerbit Gunung Agung.

Spencer, Lyle M. and Spencer, Signe M. 1993. Competence at Work. New York: John Willey.

Sugiyono. 2012. Metode Penelitian Kuantitatif, Kualitatif dan R\&D. Bandung: Alfabeta.

\section{Dokumen:}

Peraturan Kepala Badan Kepegawaian Negara Nomor 7 Tahun 2013 tentang Pedoman Perumusan Standar Kompetensi Manajerial Pegawai Negeri Sipil.

Peraturan Kepala Badan Kepegawaian Negara Nomor 8 Tahun 2013 tentang Pedoman Perumusan Standar Kompetensi Teknis Pegawai Negeri Sipil. 